\title{
POTENSI FISKAL TERHADAP PERTUMBUHAN EKONOMI DAN KESEJAHTERAAN MASYARAKAT
}

\author{
Luqman Khakim, Iwan Hermawan, Achmad Solechan, dan VS Tripriyo PS \\ Politeknik Negeri Semarang \\ Jalan Prof. H. Sudarto, SH Tembalang Semarang 50275, Indonesia Telepon +62-24-7473417 \\ E-mail: hkmluqman@gmail.com
}

Diterima 27 September 2011 / Disetujui 20 November 2011

\begin{abstract}
This research objectives are first, to determine the influence of potential fiscal (local revenue, general allocation fund, sharing fund, and other official local revenues) to local economic growth. Second, to study potential fiscal impact and local economic growth to its society welfare. The study took all population as it samples (116 cities in Java), ie: local budget realization of all cities in Java from 2007-2009 and uses panel data. Lisrel 8.54 is employed to analyze to form Structural Equation Modeling. The result shows that first, local revenues and sharing fund have positive influence to economic growth, while general allocation fund and other local revenues influence negatively to economic growth. Second, local revenues, general allocation fund and sharing fund have positive impact on local society welfare, while the other local revenues have no significant impact on it.
\end{abstract}

Keywords: potential fiscal, economic growth, local society welfare, local revenues

\begin{abstract}
Abstrak: Tujuan riset ini pertama, menentukan pengaruh potensi fiskal (Pendapatan Asli Daerah, Dana Bagi Hasil, Dana Alokasi Umum dan pendapatan daerah lainnya yang sah) terhadap pertumbuhan ekonomi daerah. Kedua, untuk mengkaji dampak potensi fiskal dan pertumbuhan ekonomi daerah terhadap kesejahteraan masyarakat. Studi ini mengambil seluruh populasi sebagai sampel (116 kota/kabupaten di Jawa) yaitu data realisasi anggaran kabupaten/kota di seluruh kota di Jawa; dan menggunakan data panel. Untuk melakukan analisis guna mengembankan SEM, digunakan software Lisrel 8.54. Hasil kajian ini menunjukkan: pertama, Pendapatan Asli Daerah dan Dana Bagi Hasil berpengaruh positif terhadap pertumbuhan ekonomi, sebaliknya Dana Alokasi Umum dan pendapatan daerah lainnya yang sah mempunyai pengaruh negatif. Kedua, pendapatan asli daerah, Dana Alokasi Umum dan Dana Bagi Hasil berdampak positif terhadap kesejahteraan masyarakat, sementara Pendapatan Daerah Lainnya yang Sah tidak mempunyai dampak yang signifikan.
\end{abstract}

Kata kunci: potensi fiskal, pertumbuhan ekonomi, kesejahteraan masyarakat, pendapatan daerah

\section{PENDAHULUAN}

Undang-undang Nomor 22 Tahun 1999 tentang Pemerintahan Daerah adalah salah satu landasan yuridis bagi pengembangan otonomi daerah di Indonesia. Dalam undang-undang ini disebutkan bahwa pengembangan otonomi pada daerah kabupaten dan kota diselenggarakan dengan memperhatikan prinsip-prinsip demokrasi, keikutsertaan masyarakat, pemerataan dan keadilan serta memperhatikan potensi dan keanekaragaman daerah. Otonomi yang diberikan kepada daerah kabupaten dan kota dilaksanakan dengan memberikan kewenangan yang luas, nyata dan bertanggung jawab kepada pemerintah daerah serta proporsional, artinya pelimpahan tanggungjawab akan diikuti oleh pengaturan, pembagian dan pemanfaatan dan sumber daya nasional yang berkeadilan serta perimbangan keuangan pusat dan daerah. 
Salah satu aspek dari pemerintahan daerah yang harus diatur secara hati-hati adalah masalah pengelolaan keuangan daerah serta anggaran pendapatan dan belanja daerah (Mardiasmo, 2004).

Pengelolaan keuangan daerah memberikan imbas terhadap nasib ekonomi suatu daerah, karena daerah menjadi maju dan sejahtera ataupun sebaliknya menjadi kategori daerah miskin dan tidak sejahtera akan tergantung pada bagaimana cara suatu daerah dalam mengelola keuangannya. Pengelolaan daerah yang dilakukan secara efisien dan efektif atau dapat dikategorikan memenuhi value for money serta partisipasi, transparansi, akuntabilitas dan keadilan akan mendorong pertumbuhan ekonomi lebih baik yang selanjutnya berujung pada peningkatan kesejahteraan masyarakat di daerah. Kemampuan suatu daerah untuk memberi standar kehidupan yang baik bagi masyarakatnya tergantung pada rata-rata jangka panjang pertumbuhan ekonominya. Dalam artian pada periode jangka panjang, dimana perbedaan yang sangat kecil dalam tingkat pertumbuhan ekonomi dapat diterjemahkan ke dalam perbedaan signifikan dalam kesejahteranan dalam lingkup individu masyarakat (Waluyo, 2004).

Aspek pemerintahan lain yang penting adalah terkait dengan anggaran pendapatan dan belanja daerah agar dilaksanakan dengan kapabilitas, efisiensi, dan efektivitas yang wajar oleh pemerintah daerah. Anggaran sebagai instrumen kebijakan dan menduduki posisi sentral harus memuat kinerja, baik dalam rangka peniaian kinerja internal maupun keterkaitannya dalam mendorong pertumbuhan ekonomi masyarakat dan meningkatkan kesejahteraan masyarakat. Kinerja yang berkaitan dengan anggaran akan berupa rasio keuangan yang membandingkan antara komponen-komponen yang terdapat pada anggaran (Hamzah, 2008). Pendanaan penyelenggaraan pemerintahan harus dilaksanakan dengan efisien dan efektif untuk mencegah tumpang tindih atau pun tidak tersedianya pendanaan pada suatu bidang pemerintahan, maka diatur pendanaan penyelenggaraan pemerintahan. Penyelenggaraan pemerintahan yang menjadi kewenangan daerah dibiayai dari $\mathrm{APBD}$, sedangkan penyelenggaraan kewenangan pemerintahan yang menjadi tanggung jawab pemerintah dibiayai dari APBN, baik kewenangan pusat yang didekonsentrasikan kepada gubernur atau ditugaskan kepada pemerintah daerah dalam rangka tugas pembantuan. Sumber-sumber pendanaan pelaksanaan pemerintahan daerah terdiri atas pendapatan asli daerah, dana perimbangan, pinjaman daerah, dan lain-lain pendapatan yang sah (Kawedar, 2008).

Penelitian ini terdiri dari dua model, dimana model pertama dalam penelitian menganalisis pengaruh komponen-komponen potensi fiskal terhadap pertumbuhan ekonomi. Istilah pertumbuhan ekonomi dan pembangunan ekonomi sebenarnya sama, namun biasanya istilah pembangunan ekonomi (economic development) lebih dikenal di negara sedang berkembang, sedangkan istilah pertumbuhan ekonomi (economic growth) lebih dikenal di negara maju (Amalia, 2007). Pertumbuhan ekonomi adalah suatu proses/perubahan yang terus menerus dan usaha suatu negara untuk memperbesar atau meningkatkan pendapatan masyarakatnya. Pertumbuhan ekonomi suatu daerah akan meningkat dipengaruhi oleh potensi fiskal dan rasio keuangan daerah. Potensi fiskal terdiri dari komponen-komponen menurut Menteri Keuangan Nomor 224/PMK.07/2008 antara lain: pendapatan asli daerah, dana alokasi umum, dana bagi hasil dan pendapatan daerah lainnya yang sah. Potensi fiskal dapat digunakan untuk mendorong dan meningkatkan pertumbuhan ekonomi yang selanjutnya meningkatkan kesejahteraan masyarakat (Abdullah dan Halim, 2003; Maemunah, 2006; Christy dan Adi, 2009).

Pada model pertama menggunakan variabel endogen yaitu pertumbuhan ekonomi, sedangkan variabel eksogen yaitu komponenkomponen potensi fiskal yang terdiri dari PAD, Dana Alokasi Umum, Dana Bagi Hasil dan Pendapatan Asli Daerah Lainnya yang Sah. Selain melakukan pengujian pengaruh variabel eksogen terhadap variabel endogen, dalam penelitian ini juga dilakukan pengujian hipotesis yang menunjukkan hubungan antarvariabel endogen yaitu model kedua penelitian ini antara pertumbuhan ekonomi terhadap kesejahteraan 
masyarakat. Model kedua yaitu pengaruh potensi fiskal dan pertumbuhan ekonomi dalam memprediksi kesejahteraan masyarakat. Kebijakan daerah yang terus meningkatkan kesejahteraan masyarakat yang optimal adalah suatu hasil interaksi proses dari masyarakat kepada pimpinan daerah (Moreno, 2005). Masyarakat dikatakan sejahtera apabila tingkat penduduk sejahteranya relatif banyak dibandingkan daerah lainnya, PDRB per kapita relatif tinggi dan angka pendidikan melek huruf yang relatif tinggi (Sabarella, 2009).

Salah satu motivasi dilakukannya penelitian ini adalah masih minimnya penelitian yang memfokuskan pada pertumbuhan ekonomi dan dampaknya pada kesejahteraan masyarakat masih relatif sedikit dilakukan di Indonesia. Dalam penelitian ini bermaksud untuk melakukan pengembangan penelitian karena adanya kesenjangan penelitian (gap research) tentang beberapa hasil penelitian yang menyisakan kelemahan, dimana menurut Ferdinand (2006) sebuah penelitian yang hasilnya masih menyisakan kelemahan atau keterbatasan perlu dilakukan upaya penelitian lanjutan karena keterbatasan tersebut dianggap sebagai masalah dalam topik yang diangkat. Oleh karena itu penelitian ini akan melakukan pengujian hipotesis dengan menggunakan penelitian repikasi ekstensi (modified research) yaitu penelitian yang mengekstensi hipotesis-hipotesis yang telah dikembangkan oleh peneliti lain untuk menghasilkan sebuah model baru yang lebih lengkap atau lebih menyeluruh atau fokus dengan beberapa hipotesis (Ferdinand, 2006).

Replikasi ekstensi yang dilakukan dalam penelitian ini mengacu pada beberapa penelitian antara lain dilakukan oleh Adi (2006) bahwa pertumbuhan ekonomi dipengaruhi oleh pen- dapatan daerah, sedangkan Kuncoro (2007) mengatakan bahwa pertumbuhan ekonomi dipengaruhi oleh dana transfer yang diteliti oleh menggunakan proksi dana alokasi. Nilai tambah dan kekhasan penelitian adalah penggunaan Path analysis dengan Lisrel 8.54 untuk memprediksi pertumbuhan ekonomi dan kesejahteraan masyarakat, sehingga akan diperoleh hasil yang lebih mendetail dalam melakukan pengujian hipotesis-hipotesisnya. Dengan analisis struktural dengan Path Analysis diharapkan mampu menganalisis pengaruh langsung dan pengaruh tidak langsung (mediating variable) antarvariabel-variabel yang akan diuji pengaruhnya.

Pulau Jawa sebagai obyek kajian dalam penelitian ini karena Pulau Jawa ternyata masih menjadi daerah yang mendominasi pertumbuhan ekonomi di seluruh Indonesia. Pulau Jawa memberikan kontribusi terbesar terhadap PDB kuartal IV/2009 sebesar 57,6 persen dengan tiga provinsi utamanya yakni DKI Jakarta sebesar 16,6 persen, Jawa Timur 14,7 persen, dan Jawa Barat (14,4 persen). Sementara, Pulau Sumatera memberikan kontribusi 23,5 persen dengan tiga provinsi terbesar yakni Riau (7,1 persen), Sumatera Utara (5,2 persen), dan Sumatera Selatan (3,1 persen). Daerah penyumbang PDB lainnya adalah Pulau Kalimantan 9,5 persen, Pulau Sulawesi 4,6 persen, dan sisanya 4,8 persen di provinsi-provinsi lainnya. Sebagai pulau yang mendominasi pertumbuhan ekonomi di Indonesia, Pulau Jawa ternyata memiliki fenomena fluktuasi pertumbuhan ekonomi antara tahun 2007-2009. Pertumbuhan ekonomi di Pulau Jawa tergolong besar, namun mengalami fluktuasi menurun pada tahun 2008, kemudian meningkat pada tahun 2009. Untuk mengetahui gap atau perbedaan persentase pertumbuhan

Tabel 1. Pertumbuhan Ekonomi Provinsi di Indonesia (\%) Tahun 2007-2009

\begin{tabular}{clrrr}
\hline No. & \multicolumn{1}{c}{ Wilayah / Pulau } & $\mathbf{2 0 0 7}$ & $\mathbf{2 0 0 8}$ & $\mathbf{2 0 0 9}$ \\
\hline 1 & Sumatera & 22,9 & 23,3 & 23,5 \\
2 & Jawa & 58,8 & 57,7 & 58,1 \\
3 & Bali dan Nusa Tenggara & 2,7 & 2,5 & 2,7 \\
4 & Kalimantan & 9,4 & 10,5 & 9,2 \\
5 & Sulawesi & 4,1 & 4,2 & 4,5 \\
6 & Maluku dan Papua & 2,1 & 1,8 & 2,0 \\
& & $100 \%$ & $100 \%$ & $100 \%$ \\
\hline
\end{tabular}

Sumber: Biro Pusat Statistik, 2010 
ekonomi di Indonesia (lihat pada Tabel 1.)

Tujuan spesifik penelitian ini adalah (1) mengkaji model pertumbuhan ekonomi daerah. Pertumbuhan ekonomi dapat juga diartikan sebagai kenaikan Gross Domestic Product (GDP) atau Gross National Product (GNP), konsep pertumbuhan ekonomi dapat dijelaskan melalui potensi fiskal atau disebut sebagai kapasitas fiskal menunjukkan gambaran kemampuan keuangan masing-masing daerah yang dicerminkan melalui pendapatan asli daerah, dana alokasi umum, dana bagi hasil dan pendapatan asli daerah lainnya yang sah yang akan dihubungkan terhadap pertumbuhan ekonomi; (2) Melakukan kajian analisis dan dampak potensi fiskal dan pertumbuhan ekonomi terhadap kesejahteraan masyarakat. Tingkat kemakmuran penduduk merupakan indikator yang mengambarkan kesejahteraan suatu daerah. Kesejahteraan masyarakat diukur melalui jumlah penduduk sejahtera. Komponen potensi fiskal dan pertumbuhan ekonomi diharapkan sejalan dengan kesejahteraan masyarakat di kabupaten/kota.

Hubungan antarvariabel eksogen dengan variabel endogen. (1) Pengaruh potensi fiskal (PAD, DAU, DBH dan PAD lainnya yang sah) terhadap pertumbuhan ekonomi. Potensi atau kapasitas fiskal adalah gambaran kemampuan keuangan masing-masing daerah yang dicerminkan melalui penerimaan umum Anggaran Pendapatan dan Belanja Daerah (tidak termasuk dana alokasi khusus, dana darurat, dana pinjaman lama, dan penerimaan lain yang penggunaannya dibatasi untuk membiayai pengeluaran tertentu) untuk membiayai tugas pemerintahan setelah dikurangi belanja pegawai dan dikaitkan dengan jumlah penduduk miskin (Peraturan Menteri Keuangan Nomor 224/ PMK/07/2008).

Potensi fiskal dapat diukur dengan komponen-komponennya terdiri dari Pendapatan Asli Daerah, Dana Bagi Hasil, Dana Alokasi Umum dan pendapatan daerah lainnya yang sah), dimana dana bagi hasil dan dana alokasi umum termasuk dalam dana transfer atau dana perimbangan. Dana Perimbangan atau dana transfer merupakan dana yang bersumber dari penerimaan Anggaran Pendapatan dan Belanja Negara (APBN) yang dialokasikan kepada daerah untuk membiayai kebutuhan daerah (Abdullah dan Halim 2006).

Komponen pertama dari potensi fiskal adalah Pendapatan Asli Daerah merupakan semua penerimaan daerah dalam bentuk peningkatan aktiva atau penurunan utang dari berbagai sumber dalam periode tahun anggaran yang bersangkutan. Komponen pendapatan daerah terdiri dari pajak daerah, retribusi daerah dan PAD lainnya; Komponen kedua adalah Dana Alokasi Umum yaitu dana yang berasal dari APBN yang dialokasikan dengan tujuan pemerataan kemampuan keuangan antar daerah untuk membiayai kebutuhan pengeluarannya dalam rangka pelaksanaan desentralisasi. Berdasarkan Undang-Undang Nomor 33 Tahun 2004 pasal 29 Proporsi DAU antardaerah provinsi dan kabupaten/kota ditetapkan berdasarkan imbangan kewenangan antara Provinsi dan Kabupaten/Kota Transfer merupakan konsekuensi dari tidak meratanya keuangan dan ekonomi daerah. Selain itu tujuan transfer adalah mengurangi kesenjangan keuangan horizontal antar-daerah, dan mengurangi kesenjangan vertikal pusat-daerah. Mengatasi persoalan efek pelayanan publik antardaerah, dan untuk menciptakan stabilitas aktivitas perekonomian di daerah (Abdullah dan Halim 2006). Komponen ketiga potensi fiskal yaitu dana bagi hasil yaitu dana yang bersumber dari pajak dan sumber daya alam. Sedangkan komponen keempat potensi fiskal yaitu PAD lainnya yang sah yaitu hasil pengelolaan kekayaan daerah yang dipisahkan merupakan penerimaan daerah yang berasal dari hasil perusahaan milik daerah dan pengelolaan kekayaan daerah yang dipisahkan. Penerimaan ini antara lain dari BPD, perusahaan daerah, dividen BPR-BKK dan penyertaan modal daerah kepada pihak ketiga. Lain-lain pendapatan asli daerah merupakan penerimaan daerah yang berasal dari lain-lain milik pemerintah daerah. Penerimaan ini berasal dari hasil penjualan barang milik daerah, dan penerimaan jasa giro.

Hasil penelitian yang dilakukan oleh Darwanto dan Yustikasari (2007) bahwa pada taraf signifikansi 10 persen dana transfer (terdiri dari dana alokasi, dana perimbangan dan dana bagi hasil) berpengaruh positif terhadap pertumbuhan daerah. Hasil tersebut berlawanan dengan 
penelitian yang dilakukan Kuncoro (2007) bahwa pertumbuhan ekonomi merupakan besaran yang diukur dari kenaikan besarnya pendapatan nasional (produksi nasional) pada periode tertentu. Nilai dari pendapatan nasional ini merupakan gambaran dari kegiatan (aktivitas ekonomi) secara nasional pada periode tertentu. Beberapa proksi untuk mengukur pertumbuhan ekonomi yang banyak digunakan yaitu Pendapatan Domestik Regional Bruto (PDRB) atau Gross National Product (GNP). Tingkat pertumbuhan ekonomi menjadi salah satu tujuan penting pemerintah daerah maupun pemerintah pusat. Upaya untuk meningkatkan pendapatan daerah akan memberikan arti apabila tidak diikuti dengan peningkatan pertumbuhan ekonomi daerah. Brata (2004) menyatakan bahwa terdapat dua komponen penerimaan daerah yang berpengaruh positif secara signifikan terhadap pertumbuhan ekonomi regional. Kedua komponen tersebut adalah PAD dan Bagian Sumbangan dan Bantuan. Namun demikian, penelitian Brata (2004) belum mencakup periode setelah otonomi daerah sehingga hubungan PAD dan Pertumbuhan ekonomi dapat saja mengarah ke hubungan negatif jika daerah terlalu ofensif dalam upaya peningkatan penerimaan daerahnya. Pertumbuhan ekonomi sering di ukur dengan mengunakan pertumbuhan produk domestik bruto (PDB/PDRB), namun demikian indikator ini dianggap tidak selalu tepat dikarenakan tidak mencerminkan makna pertumbuhan yang sebenarnya. Indikator lain, yaitu pendapatan per kapita dapat digunakan untuk mengukur pertumbuhan ekonomi (Gaspersz dan Feonay, 2003). Semakin besar pendapatan yang diperoleh daerah, maka akan semakin tinggi pertumbuhan ekonomi yang diperoleh daerah tersebut. Hasil penelitian yang dilakukan oleh Harianto dan Hari Adi (2007) bahwa pada taraf signifikansi 5 persen pendapatan daerah (PAD) berpengaruh positif terhadap pertumbuhan ekonomi. Dari pernyataan di atas, maka hipotesis model pertama $(\mathrm{H} 1-\mathrm{H} 4)$ dalam penelitian ini antara lain: H1: Pendapatan Asli Daerah berpengaruh positif terhadap Pertumbuhan Ekonomi; H2: Dana Alokasi Umum berpengaruh positif terhadap Pertumbuhan Ekonomi; H3: Dana Bagi Hasil berpenga- ruh positif terhadap Pertumbuhan Ekonomi; H4: Pendapatan Asli Daerah Lainnya yang Sah berpengaruh positif terhadap Pertumbuhan Ekonomi

Pengaruh potensi fiskal (PAD, DAU, DBH dan PAD lainnya yang sah) terhadap kesejahteraan masyarakat. Potensi fiskal sebagai kapasitas fiskal menunjukkan gambaran kemampuan keuangan masing-masing daerah yang dicerminkan melalui penerimaan umum Anggaran Pendapatan dan Belanja Daerah (tidak termasuk dana alokasi khusus, dana darurat, dana pinjaman lama, dan penerimaan lain yang penggunaannya dibatasi untuk membiayai pengeluaran tertentu) untuk membiayai tugas pemerintahan setelah dikurangi belanja pegawai. Hasil penelitian yang dilakukan Christy dan Adi, 2009 menunjukkan bahwa DAU yang merupakan komponen fiskal berpengaruh positif terhadap pertumbuhan ekonomi. Dari pernyataan di atas, maka beberapa hipotesis (H5 H8) dalam penelitian ini antara lain: H5: Pendapatan Asli Daerah berpengaruh positif terhadap Kesejahteraan Masyarakat; H6: Dana Alokasi Umum berpengaruh positif terhadap Kesejahteraan Masyarakat; H7: Dana Bagi Hasil berpengaruh positif terhadap Kesejahteraan Masyarakat; H8: Pendapatan Asli Daerah Lainnya yang Sah berpengaruh positif terhadap Kesejahteraan Masyarakat.

Pengaruh pertumbuhan ekonomi terhadap kesejahteraan masyarakat. Menurut Djoyohadikusumo (1994) suatu perekonomian dikatakan mengalami pertumbuhan atau perkembangan jika tingkat kegiatan ekonominya meningkat atau lebih tinggi jika dibandingkan dengan tahun sebelumnya. Berbeda dengan pembangunan ekonomi yang mengandung arti lebih luas dan mencakup perubahan pada tata susunan ekonomi masyarakat secara menyeluruh. Menurut Amalia (2007) istilah pertumbuhan ekonomi dan pembangunan ekonomi sebenarnya sama, namun biasanya istilah pembangunan ekonomi (economic development) lebih dikenal di negara sedang berkembang, sedangkan istilah pertumbuhan ekonomi (economic growth) lebih dikenal di negara maju. Pertumbuhan ekonomi adalah suatu proses/perubahan yang terus menerus dan usaha suatu negara untuk memperbesar atau meningkatkan penda- 
patan masyarakatnya. Pertumbuhan ekonomi suatu daerah akan meningkat dipengaruhi oleh kinerja keuangan daerah yang baik (Amalia, 2007).

Kesejahteraan masyarakat adalah tingkat kemakmuran penduduk suatu daerah atau negara dalam memenuhi kebutuhan hidup masyarakat. Kesejahteraan masyarakat dapat diukur melalui dua faktor yaitu tingkat pengangguran (ketimpangan tenaga kerja) dan tingkat kemiskinan (ketimpangan pendapatan). Pengertian pengangguran adalah penduduk yang tidak bekerja, tetapi sedang mencari pekerjaan atau sedang mempersiapkan suatu usaha baru atau penduduk yang tidak mencari pekerjaan karena tidak mungkin mendapatkan pekerjaan (discouraged workers) atau penduduk yang tidak mencari pekerjaan karena sudah diterima bekerja atau mempunyai pekerjaan tetapi belum bekerja (Putong, 2003).

Pertumbuhan ekonomi dapat diartikan perkembangan kegiatan dalam perekonomian yang menyebabkan barang dan jasa yang diproduksi dalam masyarakat bertambah dan kemakmuran masyarakat meningkat. Pertumbuhan ekonomi merupakan kemampuan suatu negara dalam menyediakan kebutuhan akan barang dan jasa kepada masyarakat dalam jumlah yang banyak sehingga memungkinkan untuk kenaikan standar hidup yang mana berdampak pula bagi penurunan tingkat pengangguran dalam jangka panjang. Semakin tinggi pertumbuhan ekonomi di daerah, maka akan semakin meningkatkan kesejahteraan masyarakat di daerah tersebut.

Hasil penelitian yang dilakukan oleh Ham- zah (2008) bahwa pada taraf signifikansi 5 persen pertumbuhan ekonomi berpengaruh positif terhadap kesejahteraan masyarakat yang diindikasikan dengan tingkat pengangguran. Dari pernyataan di atas, maka hipotesis keempat penelitian ini dapat dijelaskan. H9: Pertumbuhan Ekonomi berpengaruh positif terhadap Kesejahteraan Masyarakat

Model Penelitian. Model penelitian akan menggambarkan kosep dari rancangan operasional variabel yang implentasikan dalam dalam penelitian berupa variabel tengah (pertumbuhan ekonomi) yang dipengaruhi oleh variabel potensi fiskal (Pendapatan Asli Daerah, Dana Alokasi Umum, Dana Bagi Hasi dan PAD lainnya yang sah). Model selanjutntya pertumbuhan ekonomi yang dikur dengan laju PDRB yang digunakan untuk memprediksi kesejahteraan masyarakat dengan menggunakan indikator penduduk sejahtera. Model penelitian ini dapat diilustrasikan dalam Gambar 1.

Definisi Operasional Variabel. Definisi operasional digunakan untuk memudahkan pemahaman tentang variabel yang akan diteliti, sehingga memerlukan penegasan dan penjelasan untuk masing-masing variabel. Definisi operasional yang digunakan dalam penelitian ini dapat dijelaskan pada Tabel 2.

\section{METODE PENELITIAN}

\section{Populasi dan sampel}

Populasi adalah keseluruhan subyek penelitian. Populasi responden target dari penelitian ini

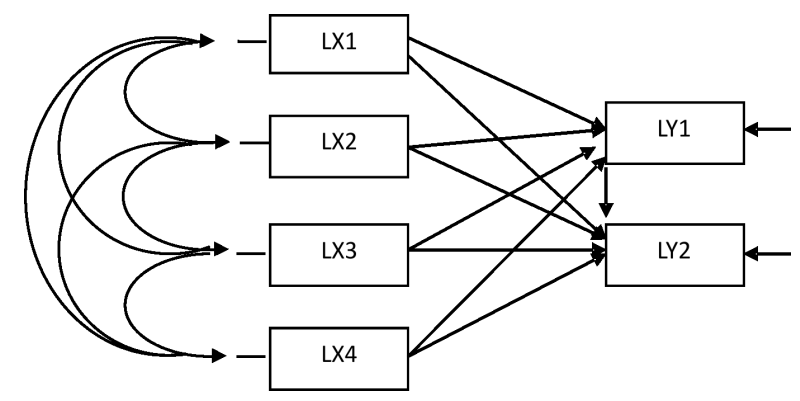

Keterangan: Potensi Fiskal (PF) terdiri dari LX1 PAD, LX2 DAU, LX3 DBH, LX4 PAD Lain Sah. Pertumbuhan ekonomi diukur dengan indikator: LY1 LAJU PDRB. Kesejahteraan Masyarakat diukur dengan indikator: LY2 Penduduk Sejahtera

Gambar 1. Model Penelitian 
Tabel 2. Definisi Konsep dan Operasional Variabel Penelitian

\begin{tabular}{|c|c|c|c|}
\hline No. & $\begin{array}{l}\text { Variabel } \\
\text { Penelitian }\end{array}$ & Definisi Konsep & $\begin{array}{l}\text { Definisi Operasional } \\
\text { (Indikator/Rumus) }\end{array}$ \\
\hline 1. & $\begin{array}{l}\text { Pendapatan } \\
\text { Asli Daerah }\end{array}$ & $\begin{array}{l}\text { Semua penerimaan daerah yang berasal } \\
\text { dari sumber ekonomi asli daerah. }\end{array}$ & $\begin{array}{l}\text { 1. Pendapatan Asli Daerah = pajak daerah, } \\
\text { retribusi daerah dan PAD lainnya. }\end{array}$ \\
\hline 2. & $\begin{array}{l}\text { Dana Alokasi } \\
\text { Umum }\end{array}$ & $\begin{array}{l}\text { Dana yang berasal dari APBN yang } \\
\text { dialokasikan dengan tujuan pemerataan } \\
\text { kemampuan keuangan antardaerah } \\
\text { untuk membiayai kebutuhan } \\
\text { pengeluarannya dalam rangka pelak- } \\
\text { sanaan desentralisasi. }\end{array}$ & $\begin{array}{l}\text { 2. Dana Alokasi Umum = Dana kesenjangan } \\
\text { keuangan horizontal antar-daerah + Dana } \\
\text { mengurangi kesenjangan vertical Pusat- } \\
\text { Daerah + | Dana mengatasi persoalan efek } \\
\text { pelayanan public antar-daerah + Dana untuk } \\
\text { menciptakan stabilitas aktivitas } \\
\text { perekonomian di daerah }\end{array}$ \\
\hline 3. & $\begin{array}{l}\text { Dana Bagi } \\
\text { Hasil }\end{array}$ & $\begin{array}{l}\text { Dana yang bersumber dari pajak dan } \\
\text { sumber daya alam, Pajak Bumi dan } \\
\text { Bangunan (PBB), Bea Perolehan Hak atas } \\
\text { Tanah dan Bangunan dan Pajak } \\
\text { Penghasilan. }\end{array}$ & $\begin{array}{l}\text { 3. Dana Bagi Hasil = Dana Perimbangan, Hibah } \\
+ \text { Dana Darurat, Bagi Hasil Pajak dari } \\
\text { Provinsi dan Pemerintah Daerah lainnya + } \\
\text { Dana Penyesuaian dan Otonomi Khusus + } \\
\text { lain-lain Pendapatan Daerah yang sah }\end{array}$ \\
\hline 4. & $\begin{array}{l}\text { Pendapatan } \\
\text { Asli Daerah } \\
\text { Lainnya yang } \\
\text { Sah }\end{array}$ & $\begin{array}{l}\text { Penerimaan daerah yang berasal dari } \\
\text { lain-lain milik pemerintah daerah. } \\
\text { Penerimaan ini berasal dari hasil } \\
\text { penjualan barang milik daerah, dan } \\
\text { penerimaan jasa giro. }\end{array}$ & $\begin{array}{l}\text { 4. PAD lainnya yang sah = BPD, perusahaan } \\
\text { daerah, dividen BPR-BKK dan penyertaan } \\
\text { modal daerah kepada pihak ketiga }\end{array}$ \\
\hline 5. & $\begin{array}{l}\text { Pertumbuhan } \\
\text { Ekonomi }\end{array}$ & $\begin{array}{l}\text { Perkembangan kegiatan dalam } \\
\text { perekonomian yang menyebabkan } \\
\text { barang dan jasa yang diproduksi dalam } \\
\text { masyarakat bertambah dan kemakmuran } \\
\text { masyarakat meningkat. }\end{array}$ & Laju PDRB $=\left(\operatorname{PDRB}_{(\mathrm{t})}-\operatorname{PDRB}_{(\mathrm{t}-1)}\right) / \operatorname{PDRB}_{(\mathrm{t}-1)}$ \\
\hline 6 & $\begin{array}{l}\text { Kesejahteraan } \\
\text { Masyarakat }\end{array}$ & $\begin{array}{l}\text { Tingkat kemakmuran penduduk suatu } \\
\text { daerah atau negara dalam memenuhi } \\
\text { kebutuhan hidup masyarakat }\end{array}$ & $\begin{array}{l}\text { Penduduk sejahtera }=\text { total jumlah penduduk - } \\
\text { jumlah penduduk miskin }\end{array}$ \\
\hline
\end{tabular}

adalah semua Pemerintah Daerah se-Kabupaten/Kota yang berada di Pulau Jawa dari Realisasi APBD tahun 2007-2009. Sampel adalah sebagian dari populasi. Dalam penelitian ini dilakukan sensus karena semua populasi diambil sebagai data penelitian yaitu mengambil semua populasi yaitu data realisasi APBD se-Jawa berada di tahun 2007-2009 sejumlah 116 sampel.

Dalam implementasinya ditunjukkan data keuangan daerah dari sebaran pemerintah kabupaten dan pemerintah kota yang tersebar di Pulau Jawa, dapat dilihat pada Tabel 3.

\section{Jenis dan prosedur pengumpulan data}

Jenis data yang digunakan dalam penelitian ini adalah data sekunder yaitu data yang diperoleh melalui perantara. Dalam penelitian ini pihak perantaranya yang dimaksud adalah data yang diterbitkan oleh Biro Pusat Statistik dan Bank Indonesia. Metode pengumpulan data yang digunakan terutama dengan cara studi dokumentasi, yaitu merupakan suatu cara yang digunakan untuk memperoleh data dengan menganalisis informasi yang didokumentasikan dalam bentuk tulisan atau bentuk-bentuk lain. Data diperoleh dari data yang diterbitkan oleh Biro Pusat Statistik dan Bank Indonesia.

\section{Alat Analisis Data}

Analisis data yang dilakukan dengan menggunakan Analisis Path (Path Analysis) dengan 
Tabel 3. Distribusi Data Sampel Pemkab dan Pemkot

\begin{tabular}{clc}
\hline No & Provinsi & Jumlah Pemkob/ Pemkot \\
\hline 1 & Jakarta & 6 \\
2 & Banten & 6 \\
3 & Jawa Barat & 26 \\
4 & Jawa Tengah & 35 \\
5 & Yogyakarta & 5 \\
6 & Jawa Timur & 38 \\
Jumlah Kota Pemkot/ Pemkab & \multicolumn{2}{|c}{116} \\
\hline
\end{tabular}

Sumber: BPS, 2010

menggunakan software LISREL 8.54. Analisis path merupakan teknik statistik yang digunakan untuk menguji hubungan kausal antara dua atau lebih variabel (Fuad dan Ghozali, 2008). Analisis path dalam penelitian ini menggunakan variabe bebas potensi fiskal (PAD, DAU, DBH dan PAD lainnya yang sah), variabel intervening yaitu pertumbuhan ekonomi (Laju PDRB) serta variabel terikat yaitu Kesejahteraan Masyarakat (Total Penduduk Sejahtera).

Dengan Path Analysis maka tidak peru dilakukan confirmatory factor analysis (CFA) yang disebabkan karena indikator yang digunakan untuk masing-masing variabel unobserved adalah satu, sehingga dinyatakan valid untuk dilakukan pengujian hipotesis.

\section{HASIL PENELITIAN}

\section{Statistik deskriptif}

Analisis statistik deskriptif variabel laten potensi fiskal terdiri dari PAD, DAU, DBH, dan PAD lainnya yang sah yang tersaji pada Tabel 4 .
Tabel 4 menunjukkan bahwa Pendapatan Asli Daerah untuk wilayah Kab/Kota se-Jawa memiliki nilai rata-rata sebesar 164.751 (dalam jutaan rupiah); nilai terendah sebesar 11.111,75 (dalam jutaan rupiah); nilai tertinggi sebesar 1.855 .758 (dalam jutaan rupiah) dan standar deviasi sebesar 379.512,19. Dana Alokasi Umum memiliki nilai rata-rata sebesar 501.297,7 (dalam jutaan rupiah); nilai terendah sebesar 0 (dalam jutaan rupiah); nilai tertinggi sebesar 1.351.912 (dalam jutaan rupiah) dan standar deviasi sebesar 339.439,15. Dana Bagi Hasil memiliki nilai rata-rata sebesar 141.880 (dalam jutaan rupiah); nilai terendah sebesar 7.886,19 (dalam jutaan rupiah); nilai tertinggi sebesar 1.590 .000 (dalam jutaan rupiah) dan standar deviasi sebesar 339.439,15. Pendapatan Lainnya yang Sah memiliki nilai rata-rata sebesar $12.362,66$ (dalam jutaan rupiah); nilai terendah sebesar 243 (dalam jutaan rupiah); nilai tertinggi sebesar 89.175 (dalam jutaan rupiah) dan standar deviasi sebesar $12.385,59$.

Analisis statistik deskriptif variabel endogen pertumbuhan ekonomi dan kesejahteraan masyarakat tersaji pada Tabel 5.

Tabel 5 mengindikasikan bahwa Pertum-

Tabel 4. Statistik Deskriptif Komponen Potensi Fiskal (PAD, DAU, DBH, dan PAD lainnya yang sah Descriptive Statistics

\begin{tabular}{lrrrrc}
\hline & N & Minimum & Maximum & Mean & Std Deviation \\
\hline Pendapatan Asli Daerah & 348 & 11111,75 & 1855758 & 164751,0 & 379512,18729 \\
Dana Alokasi Umum & 348 &, 00 & 1351912 & 501297,7 & 219541,16426 \\
Dana Bagi Hasil & 348 & 7886,19 & 1590000 & 141880,0 & 339439,15222 \\
Pendapatan lainnya yg sah & 348 & 243,00 & 89175 & 12362,7 & 12385,59573 \\
Valid N (listwise) & 348 & & & & \\
\hline
\end{tabular}

Sumber: Data yang diolah 
Tabel 5. Statistik Deskriptif Pertumbuhan Ekonomi (Laju PDRB) dan Kesejahteraan Masyarakat (Jumlah Penduduk Sejahtera)

Descriptive Statistics

\begin{tabular}{lcrrrr}
\hline & N & Minimum & Maximum & \multicolumn{1}{c}{ Mean } & Std Deviation \\
\hline PDRB & 348 & 2,02 & 14,97 & 5,1921 & 1,35405 \\
Penduduk Sejahtera & 348 & 14251,00 & 4821255 & 1024592 & 767641,25467 \\
Valid N (listwise) & 348 & & & & \\
\hline
\end{tabular}

Sumber: Data yang diolah

buhan ekonomi untuk wilayah kab/kota seJawa memiliki nilai rata-rata sebesar 5,15 persen; nilai terendah sebesar 2,02 persen; nilai tertinggi sebesar 14,97 persen dan standar deviasi sebesar 1,35. Kesejahteraan Masyarakat yaitu Penduduk Sejahtera untuk wilayah kab/kota se-Jawa memiliki nilai rata-rata sebanyak 1.024.191; nilai terendah sebesar 14.251; nilai tertinggi sebesar 4.821.255 dan standar deviasi sebesar 767.641,25. Kesejahteraan Masyarakat yaitu Upah Minimum Regional untuk wilayah kab/kota se-Jawa memiliki nilai rata-rata sebanyak 1.024.191; nilai terendah sebesar 14.251; nilai tertinggi sebesar 4.821.255 dan standar deviasi sebesar 366.739,61.

\section{Uji Normalitas Data}

Model Structural Equation Modelling (SEM) merupakan kombinasi antara regresi dengan analisis faktor, dimana data yang disajikan harus terbebas dari kondisi data yang tidak normal. Menurut Joreskog (2002) dalam Fuad dan Ghozali (2008: 38) bahwa khusus untuk data continous, transformasi data diperbolehkan. Akan tetapi untuk data ordinal, transformasi data tidak dianjurkan karena akan mengakibatkan data sulit diinterpretasikan. Tindakan transformasi dilakukan karena data asli pada masing-masing variabel manifest menunjukkan standar deviasi pada beberapa data yang jauh lebih besar dibandingkan mean dan menunjukkan distribusi data yang tidak normal seperti yang terlihat pada Tabel 6 .

Tabel 6 menunjukkan bahwa nilai Z skewness dan $Z$ kurtosis yang diperoleh dengan rumus (statistic/std error) lebih kecil dari $Z$ tabel tingkat signifikansi 5 persen sebesar 1,96 sehingga menunjukkan kondisi data yang berdistribusi tidak normal. Oleh karena itu dilakukan transformasi menjadi bilangan logaritma natural (Ln) sehingga tampak hasil uji normalitasnya pada Tabel 7.

Tabel 7 terlihat bahwa nilai probabilitas lebih besar dari tingkat signifikansi $5 \%$ pada uji skewness dan kurtosis menunjukkan kondisi data yang berdistribusi normal. Dengan demikian data yang digunakan untuk proses pengujian hipotesis menggunakan Structural Equation Modelling pada pembahasan selanjutnya menggunakan data hasil transformasi bilangan logaritma natural.

Tabel 6. Pengujian Normalitas Data Asli

Descriptive Statistics

\begin{tabular}{lcrrrr}
\hline & \multicolumn{2}{c}{$\mathbf{N}$} & \multicolumn{2}{c}{ Skewness } & \multicolumn{2}{c}{ Kurtosis } \\
\cline { 2 - 6 } & Statistic & Statistic & Std Error & Statistic & Std Error \\
\hline Pendapatan Asli Daerah & 330 &, 766 &, 134 & 1,412 &, 268 \\
Dana Alokasi Umum & 330 & $-5,977$ &, 134 & 71,051 &, 268 \\
Dana Bagi Hasil & 330 &, 770 &, 134 &, 504 &, 268 \\
Pendapatan lainnya yg & 330 &,- 119 &, 134 & 1,421 &, 268 \\
sah & 329 &,- 599 &, 134 & 3,642 &, 268 \\
PDRB & 328 & $-1,347$ &, 135 & 2,670 &, 268 \\
Penduduk Sejahtera & 327 & & & & \\
Valid N (listwise) & & & & & \\
\hline
\end{tabular}

Sumber: Data yang diolah 
Tabel 7. Pengujian Normalitas Setelah Data Ditransformasi dengan Ln

Test of Univariate Normality for Continuous Variables

\begin{tabular}{|c|c|c|c|c|c|c|}
\hline \multirow{2}{*}{ Variable } & \multicolumn{2}{|c|}{ Skewness } & \multicolumn{2}{|c|}{ Kurtosis } & \multicolumn{2}{|c|}{ Skewness \& Kurtosis } \\
\hline & Z-Score & P-Value & Z-Score & P-Value & Chi-Square & P-Value \\
\hline LX1 & 0,003 & 0,997 & 0,075 & 0,940 & 0,006 & 0,997 \\
\hline LX2 & $-0,001$ & 0,999 & 0,079 & 0,937 & 0,006 & 0,997 \\
\hline LX3 & 0,001 & 1,000 & 0,076 & 0,939 & 0,006 & 0,997 \\
\hline LX4 & 0,000 & 1,000 & 0,082 & 0,935 & 0,007 & 0,997 \\
\hline LY1 & 0,015 & 0,988 & 0,035 & 0,972 & 0,001 & 0,999 \\
\hline LY2 & $-0,021$ & 0,984 & 0,032 & 0,975 & 0,001 & 0,999 \\
\hline
\end{tabular}

Sumber: Data yang diolah

\section{Analisis model penuh (Path Analysis)}

Analisis hasil pengolahan data pada tahap full model (Path Analysis) dilakukan dengan melakukan uji kesesuaian dan uji statistik. Hasil pengolahan data untuk analisis full model Path Analysis ditampilkan pada Gambar 2.

\section{Hasil Pengujian Full Model Path Analysis}

Gambar 2 menunjukkan model fit disebabkan karena nilai chi square sangat rendah tinggi yaitu 0,000 dan nilai probabilitas sebesar 1,00 lebih besar dibandingkan taraf signifikansi $5 \%$.

\section{Goodness of fit model}

Hasil analisis goodness of fit pada full model Path Analysis dapat dilihat pada Tabel 8.

Hasil analisis pengolahan data terlihat bahwa semua manifest yang digunakan untuk membentuk sebuah model penelitian, pada proses analisis full model Path Analysis telah memenuhi kriteria goodness of fit yang telah ditetapkan. Nilai probability pada analisis ini menunjukkan nilai di atas batas signifikasi yaitu sebesar 1.000 ( $p>0.05$ dengan menggunakan taraf signifikansi 5\%). Nilai ini menunjukkan tidak adanya perbedaan antara matriks kovarian prediksi dengan matriks kovarian diestimasi. Ukuran goodness of fit pada RMSEA, menunjukkan pada kondisi yang baik.

\section{HASIL DAN PEMBAHASAN}

\section{Pengaruh Potensi Fiskal terhadap Pertum- buhan Ekonomi (H1 - H4)}

Potensi fiskal dalam penelitian ini terdiri dari 4 konstruk antara lain: pendapatan asli daerah, Dana alokasi umum, dana bagi hasil dan PAD lainnya yang sah. Dengan semakin tingginya

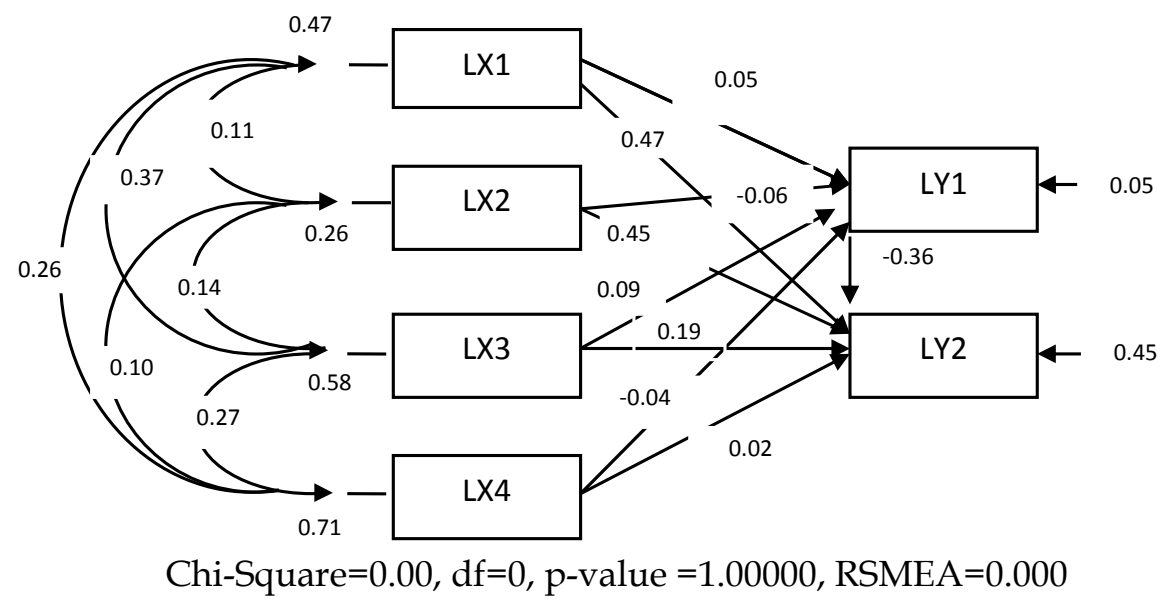

Gambar 2. Hasil Pengujian Full Model Path Analysis 
Tabel 8. Structural Equation Model (Path Analysis)

\begin{tabular}{cccc}
\hline Goodness of Fit Indeks & Cut-off value & Hasil Analisis & Evaluasi Model \\
\hline Chi-square & Kecil & 0,000 & Baik \\
Probability & $\geq 0,01$ (taraf sig. 10\%) & 1,000 & Baik \\
RMSEA & $\leq 0,08$ & 0,000 & Baik \\
\hline
\end{tabular}

Sumber: Data Penelitian yang diolah

Potensi Fiskal yang diharapkan dapat tumbuh di suatu daerah (kabupaten/kota) diharapkan mampu meningkatkan pertumbuhan ekonomi di daerah tersebut. Hal ini menjadi suatu khasanah bahwa tingkat pertumbuhan ekonomi menjadi salah satu tujuan penting pemerintah daerah maupun pemerintah pusat. Upaya untuk meningkatkan pendapatan daerah akan memberikan arti apabila tidak diikuti dengan peningkatan pertumbuhan ekonomi daerah.

Dengan melihat pengujian hipotesis pada model SEM diperoleh hasil bahwa PAD berpengaruh positif terhadap pertumbuhan ekonomi, DAU berpengaruh negatif terhadap pertumbuhan ekonomi, DBH berpengaruh positif terhadap pertumbuhan ekonomi dan PAD lainnya yang sah berpengaruh negatif terhadap pertumbuhan ekonomi.

Dengan demikian hanya hipotesis pertama dan ketiga dalam penelitian ini yang diterima yang menyatakan bahwa PAD dan DBH berpengaruh positif terhadap pertumbuhan ekonomi. Sedangkan hipotesis ketiga dan keempat tidak dapat diterima yaitu DAU dan PAD lainnya berpengaruh negatif terhadap pertumbuhan ekonomi dan tentunya hal ini tidak sesuai dengan konsep teori yang logis. Hal ini memberikan informasi penting bahwa ternyata Dana Alokasi Umum dan PAD lainnya yang sah di beberapa Kabupaten/Kotamadia yang tinggi tidak sesuai dengan pertumbuhan ekonomi di daerahnya. Oleh karena itu hasil ini perlu disikapi oleh pihak legislative agar pemberian dana alokasi umum dan PAD lainnya harus lebih merata dan diharapkan dibagikan untuk merangsang pertumbuhan ekonomi di kabupaten/kota.

\section{Pengaruh Potensi Fiskal terhadap Kesejah- teraan Masyarakat (H5 - H8)}

Hasil pengujian diperoleh bahwa PAD berpengaruh positif terhadap kesejahteraan masyarakat, DAU berpengaruh positif terhadap kesejahteraan masyarakat, DBH berpengaruh positif terhadap kesejahteraan masyarakat dan PAD lainnya yang sah tidak berpengaruh signifikan terhadap kesejahteraan masyarakat.

Dengan demikian hipotesis kelima, keenam dan ketujuh dalam penelitian ini yang diterima yang menyatakan bahwa PAD, DAU dan DBH berpengaruh positif terhadap kesejahteraan masyarakat. Sedangkan hipotesis kedelapan tidak dapat diterima yaitu PAD lainnya yang sah tidak berpengaruh terhadap kesejahteraan masyarakat. Hasil di atas terutama PAD, DAU dan $\mathrm{DBH}$ tentunya sejalan dengan program pemerintah untuk meningkatkan pembangunan dan kesejahteraan masyarakat di kabupaten/kota.

\section{Pengaruh Pertumbuhan Ekonomi terhadap Kesejahteraan Masyarakat (H9)}

Pertumbuhan ekonomi merupakan perkembangan kegiatan dalam perekonomian yang menyebabkan barang dan jasa yang diproduksi dalam masyarakat bertambah dan kemakmuran masyarakat meningkat. Semakin tinggi pertumbuhan ekonomi di daerah, maka akan semakin meningkatkan kesejahteraan masyarakat di daerah tersebut. Hasil penelitian menunjukkan bahwa pertumbuhan ekonomi berpengaruh negatif terhadap kesejahteraan masyarakat yang berarti bahwa kondisi pertumbuhan ekonomi yang terjadi di kabupaten/kota di Pulau Jawa masih belum searah dengan konsep kesejahteraan yang menjadi Tujuan Negara Indonesia: tercapainya masyarakat yang sejahtera adil dan makmur. Dengan demikian hipotesis kesembilan dalam penelitian ini tidak dapat diterima karena bertentangan dengan konsep logis dari 
penetapan hipotesis kesembilan. Hal ini tentunya sangat penting untuk diperhatikan oleh pihak eksekutif dan legislative agar pertumbuhan ekonomi yang ada di kabupaten/kota mampu mensejahterakan masyarakat karena dari hasil penelitian membuktikan bahwa ternyata pertumbuhan ekonomi yang tinggi di kabupaten/kota tidak merata karena berlawanan dengan tingkat kesejahteraan masyarakat di kabupaten/kota. Hasil ini tidak sejalan dengan hasil yang ditemukan oleh Hamzah (2008) bahwa pada taraf signifikansi $5 \%$ pertumbuhan ekonomi berpengaruh positif terhadap kesejahteraan masyarakat yang diindikasikan dengan tingkat pengangguran.

\section{SIMPULAN}

Dari hasil pengujian pengaruh potensi fiskal terhadap pertumbuhan Ekonomi dan kesejahteraan masyarakat dapat disimpulkan sebagai berikut:

Pertama, PAD berpengaruh positif terhadap pertumbuhan ekonomi, DAU berpengaruh negatif terhadap pertumbuhan ekonomi, DBH berpengaruh positif terhadap pertumbuhan ekonomi dan PAD lainnya yang sah berpengaruh negatif terhadap pertumbuhan ekonomi. Dengan demikian hanya hipotesis pertama dan ketiga dalam penelitian ini yang diterima yang menyatakan bahwa PAD dan DBH berpengaruh positif terhadap pertumbuhan ekonomi. Sedangkan hipotesis ketiga dan keempat tidak dapat diterima yaitu DAU dan PAD lainnya berpengaruh negatif terhadap pertumbuhan ekonomi.

Kedua, hasil pengujian diperoleh bahwa PAD berpengaruh positif terhadap kesejahteraan masyarakat, DAU berpengaruh positif terhadap kesejahteraan masyarakat, DBH berpengaruh positif terhadap kesejahteraan masyarakat dan PAD lainnya yang sah tidak berpengaruh signifikan terhadap kesejahteraan masyarakat. Dengan demikian hipotesis kelima, keenam dan ketujuh dalam penelitian ini yang diterima yang menyatakan bahwa PAD, DAU dan DBH berpengaruh positif terhadap kesejahteraan masyarakat. Sedangkan hipotesis kedelapan tidak dapat diterima yaitu PAD lainnya yang sah tidak berpengaruh terhadap kesejahteraan masyarakat.

Terakhir, pertumbuhan ekonomi berpengaruh negatif terhadap kesejahteraan masyarakat artinya kondisi yang terjadi di Kabupaten/ Kota se-Jawa tahun 2007-2009 menunjukkan bahwa pertumbuhan ekonomi di Kabupaten/ Kota masih belum sesuai dengan tingkat kesejahteraan masyarakat di masing-masing daerah.

Rekomendasi. Sehingga Komponen potensi fiskal yang terdiri dari: Pendapatan Asli Daerah, Dana Alokasi Umum, Dana Bagi Hasil (Pemerintah Pusat dan Daerah), Pendapatan Asli Daerah lainnya yang sah merupakan komponen yang harus diperjelas regulasinya agar alokasi anggaran yang ada memberikan imbas langsung pada pertumbuhan ekonomi dan kessejahteraan masyarakat di Kabupaten/Kota di daerah guna mensukseskan konsep otonomi dan desentralisasi.

Saran. Hasil penelitian dapat dijadikan pengambilan keputusan strategis bagi pihak eksekutif dalam rangka meningkatkan pertumbuhan ekonomi dan pencapaian kesejahteraan masyarakat. Namun demikian diperlukan analisis lanjutan yaitu indikator-indikator apasaja yang dapat mempengaruhi tata kelola pemerintahan yang baik, transparan, akuntabel dan memberikan manfaat yang signifikan bagi masyarakat di masing-masing daerah.

Pihak legislatif selaku pihak principal diharapkan mampu menjadi kontrol bagi Pemerintah Daerah yang bekerja dengan tidak menerapkan tata kelola pemerintahan yang baik. Pihak legislatif hendaknya berperan banyak dalam rangka meningkatkan pertumbuhan ekonomi daerah. Mereka merupakan penyambung lidah rakyat yang harus disampaikan kepada pemerintah agar kesejahteraan masyarakat dapat tercipta dengan adil dan merata.

\section{DAFTAR PUSTAKA}

Abdullah, Syukriy dan Halim, Abdul. 2003. Pengaruh Dana Alokasi Umum (DAU) dan Pendapatan Asli Daerah (PAD) terhadap Belanja Pemerintah Daerah: Studi Kasus Kabupaten/Kota di Jawa dan Bali. 
Jurnal Simposium Nasional Akuntansi VI Surabaya Oktober 2003.

Adi, Priyo Hari. 2006. Hubungan Antara Pertumbuhan Ekonomi Daerah, Belanja Pembangunan dan Pendapatan Asli Daerah, Jurnal Simposium Nasional Akuntansi IX Padang, 23 -26 Agustus 2006.

Adi, Priyo Hari. 2008. Relevansi Transfer Pemerintah Pusat dengan Upaya Pajak Daerah, The $2^{\text {nd }}$ National Conference 2008, Faculty of Economic Widya Mandala Catholic University.

Aji, Tony Seno. 2010. Model Alternatif untuk Membangun Sistem Informasi Perencanaan Pajak Daerah dan Retribusi Daerah. Jurnal Ekonomi Pembangunan FE UMS. Volume 11, Nomor 2, Desember 2010, hlm. 160-171. Surakarta: BPPE UMS.

Amalia, Lia. 2007. Ekonomi Pembangunan. Yogyakarta: Penerbit Graha Ilmu.

Ariadi, Dani; Lubis, Ade Fatma dan Maksum, Azhar. 2007. Pengaruh Anggaran Partisipatif melalui Budaya Organisasi, Gaya Manajemen dan Motivasi Kerja sebagai Variabel Intervening terhadap Kinerja Manajerial dan Kepuasan Kerja. Jurnal MEPA Ekonomi Vol. 2 No. 2 Mei 2007.

Arsyad, Lincolin. 1999. Pengantar Perencanaan dan Pembangunan Ekonomi Daerah. Edisi Pertama. Yogyakarta: Penerbit BPFE.

Asmoko, Hindri. 2006. Pengaruh Penganggaran Berbasis Kinerja terhadap Efektivitas Pengendalian. Jurnal Akuntansi Pemerintah Vol. 2 No. 2 November 2006.

Bank Indonesia. 2009. Ringkasan Eksekutif Bank Indonesia. Jakarta: Bank Indonesia.

Budiarto, Bambang. 2007. Pemgukuran Keberhasilan Pengelolaan Keuangan Daerah. Seminar Ekonomi Daerah. Surabaya.

Christy, Fhino Andrea dan Adi, Priyo Hari. 2009. Hubungan Antara DAU, Belanja Modal dan Kualitas Pembangunan Manusia, The 3rd National Conference UKWMS di Surabaya Oktober 2009.
Darwanto dan Yustikasari, Yulia. 2007. Pengaruh Pertumbuhan Ekonomi, Pendapatan Asli Daerah, dan Dana Alokasi Umum terhadap Pengalokasian Anggaran Belanja Modal, Jurnal Simposium Nasional Akuntansi X Makassar Juli 2007.

Djoyohadikusumo, S. 1994. Perkembangan Pemikiran Ekonomi: Dasar Teori Ekonomi Pertumbuhan dan Ekonomi Pembangunan. Jakarta: LP3ES.

Ferdinand. 2006. Stuctural Equation Modeling dalam Penelitian Manajemen. Edisi Keempat. Semarang: Universitas Diponegoro.

Fuad dan Ghozali, Imam. 2008, Strutural Equation Modeling: Teori, Konsep dan Aplikasi, Edisi II, Semarang: Badan Penerbit Universitas Diponegoro.

Fusari, Angelo. 1996. Paths of Economic Development: Modelling Factors of Endogenous Growth. International Journal of Social Economics 23, 10/11.

Ghozali, Imam, 2005, Aplikasi Analisis Multivariate dengan Program SPSS, Edisi III, Semarang: Badan Penerbit Universitas Diponegoro.

Gie, The Liang. 1997. Ensiklopedia Administrasi. Jakarta: Gunung Agung.

Halim, Abdul dan Syukriy Abdullah. 2006. Hubungan dan Masalah Keagenan di Pemerintahan Daerah: Sebuah Peluang Penelitian Anggaran dan Akuntansi. Jurnal Akuntansi Pemerintah 2(1): 53-64.

Halim, Abdul. 2004. Bunga Rampai Manajemen Keuangan Daerah. Edisi Revisi. Yogyakarta: UPP AMP YKPN.

Hamid, Edy Suandi. 2005. Ekonomi Indonesia dari Sentralisasi ke Desentralisasi. Yogyakarta: Penerbit UII Press.

Hamzah, Ardi. 2008. Analisa Kinerja Keuangan terhadap Pertumbuhan Ekonomi, Pengangguran, dan Kemiskinan: Pendekatan Analisis Jalur (Studi pada 29 Kabupaten dan 9 Kota di Provinsi Jawa Timur 
Periode 2001-2006). Jurnal Simposium Nasional Akuntansi XI Pontianak 2008.

Harianto, David dan Adi, Priyo Hari. 2007. Hubungan Antara Dana Alokasi Umum, Belanja Modal, Pendapatan Asli Daerah Dan Pendapatan Per Kapita, Jurnal Simposium Nasional Akuntansi X Makassar Juli 2007.

Indriantoro, Nur dan Supomo, Bambang. 1999. Metodologi Penelitian Bisnis untuk Akuntansi dan Manajemen. Yogyakarta: BPFE.

Iyhig, Wuan dan Bastian, Indra. 2005. Rancangan Sistem Kesejahteraan Sosial (Social Security System) di Indonesia Dalam Perspektif Akuntansi (Studi Empiris Propinsi Daerah Istimewa Yogyakarta), Jurnal Simposium Nasional Akuntansi VIII Solo.

Jaryanto. 2008. Pengaruh Desentralisasi terhadap Kinerja Manajerial dengan Sistem Akuntansi Manajemen (Broadscope, timeliness, Aggregation, dan Integration) sebagai Variabel Intervening (Studi Pada Perusahaan Manufaktur di Jawa Tengah). Jurnal Fokus Ekonomi Vol. 3 No. 2 Desember 2008.

Jones R dan Pendlebury M, 1996. Public Sector Accounting. London: Pitman Publishing.

Kadjatmiko, 2001. Perhitungan dan Penetapan Dana Alokasi Umum, Makalah disampaikan dalam Rapat Kerja Teknis Keuangan Daerah dengan tema Peningkatan Efisiensi dan Efektivitas Pengelolaan Keuangan Daerah Upaya Menunjang Keberhasilan Pelaksanaan Otonomi Daerah, Jakarta September 2001.

Kawedar, Warsito; Rohman, Abdul; Handayani, Sri. 2008. Akuntansi Sektor Publik: Pendekatan Penganggaran Daerah dan Akuntansi Keuangan Daerah. Semarang: Badan Penerbit Universitas Diponegoro.

Keni dan Dewi, Sofia Prima. 2008. Peranan Partisipasi Penyusunan Anggaran dan Akuntansi Pertanggungjawaban terhadap
Akuntabilitas Kinerja. Jurnal Manajemen Tahun XII No. 2 Juni 2008.

Kowalczyk, Tamara; Rafai, Savya dan Taylor, Audrey. 2006. An Experimental Investigation of Strategic Budgeting: A Techniques for Integrating Information Symmetry. Journal Management Accounting Vol. 15-20.

Kuncoro, Haryo. 2007. Fenomena Flypaper Effect Pada Kinerja Keuangan Pemerintah Daerah Kota dan Kabupaten di Indonesia. Jurnal Simposium Nasional Akuntansi X Makassar.

Kuncoro, Mudrajad. 2004. Otonomi dan Pembangunan Daerah: Reformasi, Perencanaan, Strategi dan Peluang. Jakarta: Penerbit Erlangga.

Lukito, Edy dan Noegroho, Yefta Andi Kus. 2008. Pengaruh Informasi Akuntansi terhadap Kinerja Manajer dengan Ketidakpastian Lingkungan dan Strategi Bisnis sebagai Variabel Pemoderasi. Jurnal Akuntansi dan Bisnis Vol. 8 No. 1 Februari 2008.

Mahmudi. 2007. Analisis Laporan Keuangan Pemerintah Daerah: Panduan Bagi Eksekutif, DPRD dan Masyarakat dalam Pengambilan Keputusan Ekonomi, Sosial dan Politik. Buku Seri Membudayakan Akuntabilitas Publik. Yogyakarta: UPP STIM YKPN.

Mahmudi. 2010. Manajemen Kinerja Sektor Publik. Edisi Kedua. Yogyakarta: UPP STIM YKPN.

Maimunah, Mutiara. 2006. Flypaper Effect Pada Dana Alokasi Umum (DAU) dan Pendapatan Asli Daerah (PAD) Terhadap Belanja Daerah Pada Kabupaten/Kota Di Pulau Sumatera, Jurnal Simposium Nasional Akuntansi IX Padang.

Mardiasmo. 2004. Otonomi dan Manajemen Keuangan Daerah. Yogyakarta: Penerbit Andi.

Murtanto dan Hapsari, Winda Arum. 2006. Pengaruh Partisipasi Penyusunan Anggaran terhadap Kinerja Manajerial dengan Desentralisasi dan Karakteristik Sistem In- 
formasi Akuntansi Manajemen sebagai Variabel Moderating. Jurnal Bisnis dan Akuntansi Vol. 8 No. 1 April 2006.

Muslimin. 2007. Pengaruh Pengendalian Akuntansi, Pengendalian Perilaku dan Pengendalian Personal terhadap Kinerja Manajerial pada PT. Berkat Agung Jaya Abadi Gresik. Jurnal Aplikasi Manajemen Vol. 5 No. 3 Desember 2007.

Nasir, Mohamad. 2009. Hubungan Anggaran Partisipatif, Kecukupan Anggaran, Komitmen Organisasi, Motivasi dan Kinerja Manajerial dengan Model Persamaan Struktural. Jurnal Media Riset Akuntansi, Auditing, dan Informasi Vol. 9 No. 3 Desember 2009.

Ndadari, Laras Wulan dan Adi, Priyo Hari. 2008. Perilaku Asimetris Pemerintah Daerah terhadap Transfer Pemerintah Pusat. The 2nd National Conference UKWMS di Surabaya September 2008.

Peraturan Menteri Dalam Negeri Nomor 13 tahun 2006 tentang Pedoman Pengelolaan Keuangan Daerah.

Peraturan Menteri Keuangan No. 224 / PMK/ 07/2008 tentang Peta Kapasitas Fiskal Daerah.

Pramuka, Bambang Agus. 2010. Flypaper Effect pada Pengeluaran Pemerintah Daerah di Jawa. Jurnal Ekonomi Pembangunan FE UMS Volume 11, Nomor 1, Juni 2010, hlm.1-12. Surakarta: BPPE UMS.

Putong, Iskandar. 2003. Ekonomi Mikro dan Makro. Edisi 2. Jakarta: Penerbit Ghalia Indonesia.

Rachmad, M. 1997. Analisis Perilaku Masyarakat Miskin dan Hubungan antara Aktivitas Ekonomi dengan Derajat Kemiskinan Masyarakat Desa Tertinggal di Sepanjang Sungai Batang Hari. Jurnal Manajemen dan Pembangunan Edisi - 7 Juli.

Republik Indonesia, Undang-undang No. 25 tahun 1999 tentang Perimbangan Keuang- an antara Pemerintah Pusat dan Pemerintah Daerah.

Rinarti, Deasy dan Renyowijoyo, Muindro. 2007. Pengaruh Ketidakpastian Lingkungan dan Budaya Organisasi terhadap Partisipasi Penganggaran dan Kinerja Manajerial. Jurnal Bisnis dan Akuntansi Vol. 9 No. 2 Agustus 2007.

Ronald, Andreas. 2010. Analisis Kinerja Keuangan dan Pertumbuhan Ekonomi Sebelum dan Sesudah Diberlakukannya Otonomi Daerah di Kabupaten Kulonprogo. Jurnal Bisnis dan Ekonomi Vol. 1 No. 1 Juni 2010.

Sasana, Hadi. 2009. Peran Desentralisasi Fiskal terhadap Kinerja Ekonomi di Kabupaten/Kota Provinsi Jawa Tengah. Jurnal Ekonomi Pembangunan Volume 10 No.1 Juni.

Sjahrial, Dermawan. 2006. Pengaruh Strategi Manajerial terhadap Hubungan antara Penggunaan Anggaran dengan Peningkatan Kinerja Manajerial. Jurnal Bisnis dan Akuntansi Vol. 8 No. 1 April 2006.

Solechan, Achmad dan Setiawati, Ira. 2009. Pengaruh Karakteristik Sistem Akuntansi Manajemen dan Desentralisasi sebagai Variabel Moderating terhadap Kinerja Manajerial (Studi Empiris Perusahaan Manufaktur di Kabupaten Semarang). Jurnal Fokus Ekonomi Vol. 4 No. 1 Juni 2009.

Stede, Wim A. Van Der. 2000. The relationship between Two Consequences of Budgetary Controls: Budgetary Slack Creation and Managerial Short-Term Orientation. Journal Accounting, Organization and Society 25.

Subiyanto, Ibnu dan Halim, Abdul. 2008. Analisis Investasi (Belanja Modal) Sektor Publik-Pemerintah Daerah. Yogyakarta: UPP STIM YKPN.

Sumarsono, Sony. 2009. Teori dan Kebijakan Publik Ekonomi Sumber Daya Manusia. Cetakan Pertama. Yogyakarta: Graha Ilmu. 
Tangkau, Jaqueline. 2009. Analisis Pengaruh Komitmen Organisasional dan Partisipasi Anggaran terhadap Kinerja Manajerial dan Senjangan Anggaran (Budgetary Slack). Jurnal FORMAS Vol. 2 No. 4 Juni 2009.

Tarigan, R. 2004. Ekonomi Regional, Teori dan Aplikasi. Jakarta: PT. Bumi Aksara.

Todaro, MP. 1997. Pembangunan Ekonomi. Edisi Kesembilan. Jakarta: Penerbit Erlangga.

Tuati, Nonce F. 2007. Pengaruh Desentralisasi dan Pengendalian Intern terhadap Kinerja Manajerial (Studi Empiris pada Pemerin- tah Kota Kupang). Jurnal MITRA Tahun XIII Nomor 3 tahun 2007.

Umar, Husein. 2002. Metode Riset Bisnis. Jakarta: PT. Gramedia Pustaka Utama.

Waluyo, Dwi Eko. 2004. Teori Ekonomi Makro. Malang: UMM Press.

Wijono, Wiloejo Wirjo. 2006. Mengungkap Sumber-sumber Pertumbuhan Ekonomi Indonesia dalam Lima Tahun Terakhir. Jurnal Manajemen dan Fiskal Volume V No. 2. 